\title{
Cywilnoprawne aspekty umów zawieranych pomiędzy organem administracji publicznej a organizacją pozarządową w celu realizacji zadań publicznych
}

\section{Wprowadzenie}

Transformacja ustrojowa oraz reaktywacja samorządu terytorialnego $\mathrm{w}$ istotnym stopniu zmieniły zasady funkcjonowania administracji publicznej w Polsce. W stosunku do okresu sprzed 1989 r. przekształceniu poddany został w części zakres przedmiotowy realizowanych zadań publicznych oraz metody i formy ich realizacji. Niewatpliwie, zmianie uległ katalog podmiotów posiadających uprawnienia bądź obowiązek przedsiębrania aktywności w imieniu administracji publicznej. Zarówno w doktrynie prawa administracyjnego, jak i przyjętych przez ustawodawcę rozwiązaniach normatywnych zaobserwować można intensyfikację działań zmierzających do propagowania oraz wdrażania regulacji nakierowanych na rozszerzenie i rozwój form decentralizacji administracji publicznej. Zjawisko decentralizacji odnosi się również do problematyki angażowania podmiotów niepublicznych w zaspokajanie potrzeb wspólnoty samorządowej.

Niniejszy artykuł koncentruje się na wybranych aspektach współpracy z organizacjami pożytku publicznego (OPP), które wspomagają organy władzy publicznej w wykonywaniu ich ustawowych zadań. OPP, zaliczone do trzeciego sektora ${ }^{1}$, są coraz istotniejszym uczestnikiem funkcjonowania

${ }^{1}$ Określenie „trzeci sektor" oznacza ogół organizacji pozarządowych i jest wyrazem teorii nowoczesnego państwa, którego działania dzielą się na sektory: państwowy, 
państwa i samorządu na każdym szczeblu terytorialnym. Z jednej strony organizacje te umożliwiają rozwijanie aktywności obywatelskiej, a z drugiej przyczyniają się do efektywniejszej realizacji zadań publicznych. Z pewnością należy dążyć do tego, by relacje między organami władzy publicznej i tymi organizacjami budowane były na partnerskich zasadach.

W obszarze rozwijania współpracy przełomowym wydarzeniem było uchwalenie Ustawy z dnia 24 kwietnia 2003 r. o działalności pożytku publicznego i o wolontariacie ${ }^{2}$. Ustawa ta jest dużym osiągnięciem na drodze ustrojowych regulacji prawnych między administracją publiczną i organizacjami pozarządowymi, gdyż po raz pierwszy w polskim prawodawstwie w sposób zasadniczy uregulowano zasady współpracy organizacji pozarządowych z administracją samorządowa, a także tryb zlecania zadań publicznych. Współpraca administracji publicznej z organizacjami pozarządowymi oraz podmiotami wymienionymi w art. 3 ust. 3 u.d.p.p.w. na rzecz realizacji zadań publicznych określonych w art. 4 u.d.p.p.w. wydaje się niepodważalna, ponieważ wspólne cele i zaangażowanie są podłożem kształtowania społeczeństwa obywatelskiego. Ponadto przydatność tejże współpracy widoczna jest szczególnie na tle zasady pomocniczości aprobującej wspólne działania i realizację lokalnych oraz regionalnych potrzeb społeczeństwa. Ważne jest zatem, by proces ten w sposób dostateczny wspierany był przez istniejące w tym zakresie mechanizmy prawne i ekonomiczne.

Nie ulega wątpliwości, że administracja publiczna działająca $\mathrm{w}$ ramach dominium posługuje się formami charakterystycznymi dla prawa cywilnego, choć cywilistyczny rdzeń obudowany został przepisami szczególnymi ze względu na specyfikę jej funkcjonowania ${ }^{3}$. Tematyka dotycząca działań podejmowanych przez organizacje pozarządowe w sferze zadań publicznych była już niejednokrotnie podnoszona w piśmiennictwie ${ }^{4}$, jednakże kwestia umów zawieranych pomiędzy organem administracji publicznej a organizacjami pozarządowymi znajduje jedynie fragmentaryczne odzwierciedlenie w literaturze przedmiotu. Pomimo obszernego piśmiennictwa dotyczącego prawnych form działania

rynkowy oraz organizacji non profit, zob. P. Staszczyk, Ustawa o działalności pożytku publicznego i o wolontariacie. Komentarz, Warszawa 2013, s. 9.

${ }^{2}$ Tekst jedn. Dz.U. 2019, poz. 688 ze zm., dalej „u.d.p.p.w.”.

${ }^{3}$ P. Stec, Umowy w administracji. Studium cywilnoprawne, Warszawa 2013, s. 13.

${ }^{4}$ K. Kietlińska, Rola trzeciego sektora w społeczeństwie obywatelskim, Warszawa 2010, s. 53; Z. Lasocik, Kilka uwag o roli organizacji pozarządowych w państwie demokratycznym, Warszawa 1994, s. 12; E. Keti, The possible role of the nonprofit sektor in Hungary, Baltimore 1989, s. 14. 
$\mathrm{w}$ administracji ${ }^{5}, \mathrm{w}$ tym umów $\mathrm{w}$ administracji ${ }^{6}$, umowy zawierane stricte $\mathrm{z}$ organizacjami pozarządowymi w celu realizacji zadań publicznych nie doczekały się głębszej refleksji teoretycznej ze strony doktryny zarówno prawa cywilnego, jak i prawa administracyjnego. Właśnie ta luka dała asumpt do podjęcia tej problematyki.

Należy zaznaczyć, że analizy dogmatycznej umów nie ułatwia też sam ustawodawca, odwołując się często do przepisów prawa cywilnego w sposób przypadkowy, kierując się raczej doraźną potrzebą niż spójną logiką i strategią działania. Niewątpliwie, pojawia się zatem potrzeba analizy umów w administracji publicznej z punktu widzenia prawa cywilnego, zwłaszcza pod kątem zgodności z fundamentalnymi zasadami prawa cywilnego, jakimi są autonomia woli stron oraz swoboda umów.

W zakresie swobody umów szeroką konstrukcję na gruncie przepisów Kodeksu cywilnego sprzed 1990 r. zaproponował Z. Radwański. Zdaniem autora wyznacza ona "kompetencję do kształtowania przez podmioty prawa cywilnego stosunków prawnych w drodze umów"7. Współcześnie do koncepcji tej nawiązuje P. Machnikowski, traktując swobodę umów jako ustanowioną dla podmiotów prawa cywilnego możność (kompetencję) do ustanawiania, uchylania oraz zmieniania ich obowiązków w drodze podejmowanych czynności, czyli w drodze zawierania umów ${ }^{8}$. W przypadku umów w administracji, w obszarze niniejszych rozważań ustawodawca ogranicza swobodę umów, wyliczając zakres zadań należący do sfery publicznej (art. 4 u.d.p.p.w.), a więc jej przedmiot, a także poprzez wyłączenie podmiotów mogących brać udział w obrocie prawnym (art. 3 u.d.p.p.w.).

${ }^{5} \mathrm{~W}$ tym miejscu trudno przytoczyć w całości obszerną literaturę dotyczącą prawnych form działania administracji - zob. np. M. Zimmermann, Formy działania administracji i administracyjne, w: Prawo administracyjne, cz. 2, pod red. M. Jaroszyńskiego, Warszawa 1952, s. 91 i n.; J. Starościak, Prawne formy działania administracji, Warszawa 1957; idem; Prawne formy i metody działania administracji, w: System prawa administracyjnego, t. 3, pod red. T. Rabskiej, J. Łętowskiego, Warszawa 1978, s. 39-129; J. Łętowski, Prawo administracyjne. Zagadnienia podstawowe, Warszawa 1990, s. 128-209.

${ }^{6}$ B. Jaworska-Dębska, Umowy we współczesnej administracji, w: Umowy w administracji, pod red. J. Bocia, L. Drzewięckiej-Bokun, Wrocław 2008, s. 14; Z. Cieślik, Umowa administracyjna państwa prawa, Kraków 2004, s. 85; M. Kania, Umowa jako prawna forma działania administracji publicznej, w: Publiczne prawo gospodarcze, seria System Prawa Administracyjnego, pod red. R. Hausera, Z. Niewiadomskiego, A. Wróbla, t. 8B, Warszawa 2013, s. 510-543.

7 Z. Radwański, Umowy, w: System Prawa Cywilnego, t. 3, cz. 1: Prawo zobowiąań. Czesść ogólna, Warszawa 1981, s. 360.

8 P. Machnikowski, Swoboda umów według art. 353(1) k.c., Warszawa 2005, s. 2. 
Współpraca pomiędzy organem administracji publicznej a organizacjami pozarządowymi, w konsekwencji której zawierana jest umowa, odbywa się przede wszystkim poprzez zlecanie realizacji zadań $\mathrm{w}$ formie powierzania lub wspierania $\mathrm{w}$ trybie otwartego konkursu lub w uzasadnionych przypadkach $\mathrm{z}$ jego pominięciem oraz $\mathrm{w}$ ramach inicjatywy lokalnej.

\section{Istota i charakter prawny umowy jako formy działania administracji publicznej}

Wszelkie refleksje nad istotą i charakterem prawnym umów jako form działania administracji są $\mathrm{w}$ dalszym ciągu wyzwaniem dla nauki prawa administracyjnego. W polskim ustawodawstwie jak dotąd trudno mówić o wykształceniu się spójnej instytucji umowy administracyjnej, co przyznają nawet sami administratywiści ${ }^{9}$. Polskie prawodawstwo pomimo podjętych już prób ${ }^{10}$ nie wypracowało więc jeszcze, o ile kiedykolwiek zdoła wypracować, całościowej teorii umów administracyjnych.

W doktrynie prawa administracyjnego współegzystują dwa przeciwstawne poglądy. Pierwsza grupa autorów kwestionuje sens tworzenia odrębnej kategorii umów prawa administracyjnego ${ }^{11}$, druga grupa nato-

${ }^{9}$ A. Taras, A. Wróbel, W sprawie jednolitej koncepcji umów publicznych, w: Prawo administracyjne w okresie transformacji ustrojowej, pod red. E. Knosali, A. Matana, G. Łaszczycy, Kraków 1999, s. 124; J. Boć, Działalność konsensualna (dwustronna i wielostronna), w: Prawne formy działania administracji, pod red. R. Hausera, Z. Niewiadomskiego, A. Wróbla, Warszawa 2013, s. 252; L. Staniszewska, Zagadnienia konstrukcyjne umów publicznoprawnych, "Studia Prawa Publicznego" 2019, nr 3, s. 140.

${ }^{10}$ Polski ustawodawca po raz pierwszy rozważał wprowadzenie umowy administracyjnej do polskiego systemu projektem z dnia 29 XII 2010 r. ustawy - Przepisy ogólne prawa administracyjnego (druk sejmowy nr 3942/VII kadencja); następnie, w nowelizacji k.p.a. (w latach 2016-2017) również pojawiła się propozycja włączenia umowy administracyjnej do tego aktu. W następstwie została jednak wyłączona z projektu jeszcze przed etapem rozpoczęcia prac parlamentarnych.

${ }^{11} \mathrm{~J}$. Zimmermann opowiadał się za wydzieleniem z projektów przepisów poświęconych umowie jako formie działania administracji. Autor postulował napisanie odrębnej ustawy regulującej tę problematykę. Argumentował, że problematyka umów i porozumień w administracji nie należy do „ogólnej”, "ale jest dość specyficzna z punktu widzenia istoty prawa administracyjnego i jego całości". Według autora porozumienia i umowy administracyjne muszą ustępować decyzjom administracyjnym i pozostawać wobec nich na drugim planie. Zob. J. Zimmermann, Przepisy ogólne prawa administracyjnego, Warszawa 2009, s. 170. A. Panusiak definiuje je jako dwustronny, elastyczny stosunek prawny nawiązany między podmiotami publicznymi lub podmiotem publicznym i podmiotem prywatnym, którego celem jest realizacja zadań publicznych. Zob. A. Panusiak, Koncesja 
miast uważa, że podjęcie wysiłku w celu wyodrębnienia osobnej umowy w prawie administracyjnym jest jak najbardziej zasadne ${ }^{12}$. Podkreślają jednocześnie podział prawa na prawo publiczne i prywatne ${ }^{13}$. Przy czym należy zaznaczyć, że ma on znaczenie w wymiarze metodologicznym, tzn. że nie odnosi się tylko do systemu prawnego, lecz dotyczy także nauki prawa ${ }^{14}$. Podział ten, co trzeba zaakcentować, traktowany jest niekiedy jako "dobre" prawo cywilne i "złe" prawo administracyjne - „złe", bo posługuje się metodą władczą ${ }^{15}$. Teoretycy wielokrotnie zgłaszali zarzuty wobec tego rozróżnienia ${ }^{16}$, co może być podstawą do zakwestionowania sensowności tego podziału. W literaturze podkreśla się, że „podział nie jest sprawą poznania, lecz sprawą aprobaty, uznania określonej wartości i określonej ideologii politycznej"17.

Istotna zatem $\mathrm{w}$ obecnym stanie prawnym wydaje się próba ustalenia charakteru prawnego umowy o wykonanie zadania publicznego. Niewątpliwie, użyte pojęcie „umowa w administracji” nie ma umocowania normatywnego. $\mathrm{W}$ doktrynie pojawiają się takie sformułowania, jak: umowa administracyjna, umowa publicznoprawna, umowa cywilnoprawna ${ }^{18}$. Nadto prezentowane są stanowiska, w których jako przykład umowy publicznoprawnej wskazuje się porozumienie administracyjne zawierane pomiędzy dwoma względnie równorzędnymi podmiotami prawa publicznego $\mathrm{w}$ przedmiocie wykonywania ich

na roboty budowlane lub ustugi. Partnerstwo publiczno-prywatne. Komentarz, Warszawa 2009, s. 192-194.

${ }^{12} \mathrm{~J}$. Lemańska, Umowa administracyjnoprawna a umowa cywilnoprawna, w: Instytucje współczesnego prawa administracyjnego. Księga jubileuszowa prof. zw. dra hab. Józefa Filipka, pod red. I. Skrzydło-Niżnik, Kraków 2001, s. 421 i n.; J. Wyporska-Frankiewicz, Publicznoprawne formy działania administracji o charakterze dwustronnym, Warszawa 2010, s. 237 i n.; D. Kijowski, Umowy w administracji publicznej, w: Podmioty administracji publicznej i prawne formy ich działania. Studia i materiały z konferencji naukowej poświęconej jubileuszowi 80-tych urodzin Profesora Eugeniusza Ochendowskiego, Toruń 2005, s. 282 i n.

${ }^{13}$ M. Lemonnier, Prawo publiczne a prawo prywatne. Uwagi prawnoporównawcze na podstawie prawa francuskiego, "Studia Prawno-Ekonomiczne” 2016, t. 100, s. 67 i n.; I. Zachariasz, Prawo w ujęciu strukturalnym. Studium o dychotomicznym podziale prawa na prawo publiczne i prawo prywatne, Warszawa 2016, s. 10.

${ }^{14}$ J. Nowacki, Prawo publiczne - prawo prywatne, Katowice 1992, s. 12.

${ }^{15}$ E. Lętowska, Prawo cywilne a prawo administracyjne. Razem, ale nie do spótki. "Dobre" prawo cywilne, "złe" prawo administracyjne, w: A. Mączyński, M. Pazdan, A. Szpunar, Rozprawy z polskiego i europejskiego prawa prywatnego. Ksiegga pamiatkowa ofiarowana profesorowi Józefowi Skąskiemu, Kraków 1994, s. 221.

${ }^{16}$ J. Nowacki, op. cit., s. 6; J. Zimmermann, Aksjomaty prawa administracyjnego, Warszawa 2013, s. 55.

${ }^{17}$ Ibidem, s. 107.

${ }^{18}$ P. Panusiak, Umowa publicznoprawna. Próba definicji, „Państwo i Prawo” 2008, z. 2, s. 18. 
ustawowych zadań publicznych ${ }^{19}$. Strategiczne spostrzeżenie w kwestii umowy administracyjnej zaprezentowała B. Popowska ${ }^{20}$, odnosząc się do umowy administracyjnej w prawie niemieckim. Niemiecka ustawa wyróżnia dwa rodzaje umowy administracyjnej: koordynacyjnoprawną i subordynacyjnoprawną. Kryterium tego podziału stanowi rodzaj relacji między stronami, które przystępują do negocjacji prowadzących do zawarcia umowy ${ }^{21}$.

H. Izdebski twierdzi, że umowa publicznoprawna ma pewne cechy umowy cywilnoprawnej, gdyż w zakresie nieuregulowanym stosuje się przepisy Kodeksu cywilnego ${ }^{22}$, niemniej jest również nierozerwalnie związana $\mathrm{z}$ aktem prawa publicznego, co ma miejsce $\mathrm{w}$ przypadku ramowych wzorów umów, o których mowa w art. 19 ust. 2 u.d.p.p.w. Inni autorzy uznaja, że jeśli podmiot prywatny realizuje zadania publiczne, to być może są to umowy publicznoprawne ${ }^{23}$. Niewątpliwie umowy, których stroną są podmioty administracji publicznej, częstokroć cechuje niejednolity charakter prawny. Oznacza to, że poddane są one regulacji zarówno prawa prywatnego, jak i prawa publicznego ${ }^{24}$. Usytuowanie organów administracji ma zdecydowanie charakter nadrzędny nad organizacjami pozarządowymi. Są one decydentami w zakresie ich zlecania oraz podmiotami uprawnionymi do sprawowania kontroli poprzez złożenie przez OPP sprawozdań z realizacji wykonania zadań, o których mowa w art. 18 u.d.p.p.w.

Z pewnością umowa $\mathrm{w}$ administracji to jedna $\mathrm{z}$ tych form działania administracji, które mają być przeciwwagą dla aktu administracyjnego jako instrumentu władczego ${ }^{25} \mathrm{i}$ jednostronnego narzucania woli przez władzę publiczną. Co więcej, umowa jest najbardziej naturalnym

${ }^{19}$ J. Filipek, Prawo administracyjne, instytucje ogólne, cz. 2, Kraków 2001, s. 141; J. Zimmermann, Prawo administracyjne, Kraków 2005, s. 405 i n.; J. Starościak, System prawa administracyjnego, Warszawa 1977, s. 247 i n.

${ }^{20}$ B. Popowska, Decyzja i umowa jako formy działania podmiotów administracji gospodarczej; konkurencja, współwystępowanie czy alternatywa?, Poznań 2009, s. 113.

${ }^{21}$ L. Staniszewska, op. cit., s. 146.

${ }^{22}$ Ustawa z dnia 23 IV 1964 r. Kodeks cywilny (tekst jedn. Dz.U. 2019, poz. 1145 ze zm.), dalej k.c.; H. Izdebski, Fundacje i stowarzyszenia. Komentarz, Warszawa 2003, s. 180.

${ }^{23}$ P. Kledzik, Działalność organizacji pozarządowych na rzecz realizacji celów publicznych, Warszawa 2013, s. 172.

${ }^{24}$ L. Wengler, Zagadnienia wykorzystywania umowy publicznoprawnej dla usprawnienia realizacji zadan administracji publicznej, w: Z. Niewiadomski, Z. Cieślak, Prawo do dobrej administracji, Warszawa 2003, s. 217-218.

${ }^{25} \mathrm{~K}$. Ziemski, Indywidualny akt administracyjny jako forma prawna działania administracji, Poznań 2005, s. 15-76, 118-137 i n.; E. Szewczyk, M. Szewczyk, Generalny akt 
sposobem regulacji stosunków międzyludzkich zmierzającym do kompromisu, a tym samym do uniknięcia konfliktu ${ }^{26}$, co wspomaga elastyczność administracji. Bez niej, wydaje się, nie można w pełni efektywnie realizować zadań publicznych.

Odpowiedzi na pytanie, z jakim charakterem prawnym umowy $\mathrm{w}$ administracji mamy do czynienia, nie ułatwia fakt, że w ogólnej nauce prawa konstrukcja każdej umowy jest identyczna. Chodzi bowiem o oświadczenie woli co najmniej dwóch stron, które są względem siebie równorzędne. Ponadto nie można zapominać, że istota umowy najbardziej współgra z naturą prawa cywilnego, czyli mówiąc szerzej, prawa prywatnego. Celem prawa cywilnego jest umożliwienie maksymalnej i nieskrępowanej współpracy ludzi jako podmiotów wolnych i równych. W konsekwencji podmioty te powinny mieć możliwość samodzielnego kreowania stosunków zachodzących między nimi. By prawo cywilne spełniało swoje funkcje, musi mieć charakter systemu otwartego, który w sposób nieautorytatywny reguluje sytuacje typowe ${ }^{27}$. Zasadnicza jest odpowiedź na pytanie, na ile taki sposób myślenia może być przeniesiony na grunt prawa publicznego.

Termin "umowa o współpracy” jest często używany w prawie administracyjnym do określenia umów o różnym charakterze. Niewątpliwie, w swojej treści wiele umów zawiera postanowienia o współdziałaniu stron. Umowy te bezsprzecznie są umowami zobowiązującymi, a w konsekwencji jednoznacznie precyzują zakres zobowiązań stron umowy. Co istotne, u.d.p.p.w. także odwołuje się do k.c., o czym przesądza art. 19h. Nasuwa się więc pytanie, czy swoboda kontraktowania jako podstawowa zasada prawa cywilnego ma zastosowanie do umów zawieranych pomiędzy organami administracji publicznej a organizacjami pozarządowymi w związku z realizacją zadań określonych w u.d.p.p.w. W opracowaniu prezentowane jest stanowisko (hipoteza), że zasada ta ma zastosowanie, ale w ograniczonym zakresie, gdyż bez pewnego minimum autonomii i swobody stron byłaby karykaturą.

Należy podkreślić, że podmioty administracji, korzystając z form cywilnoprawnych, opierają swoje działania na regulacjach zawartych w przepisach k.c., z tym że regulacje te są w wielu ujęciach modyfikowane

administracyjny, Poznań 2014, s. 234 i n.; J. Boć, Działalność konsensualna..., s. 237; J. Łukasiewicz, K. Kłosowska, Słowo o przyrzeczeniu administracyjnym, w: Umowy w administracji, s. 100.

${ }^{26}$ V. Schlette, Die Verwaltung als Vertragspartner, Tübingen 2000, s. 14.

${ }^{27}$ I.C. Kamiński, Stuszność i prawo. Szkic prawnoporównawuczy, Kraków 2003, s. 25. 
przepisami prawa administracyjnego. Niemniej jednak administracja publiczna, działająca wielekroć z pozycji władztwa administracyjnego, posługuje się także niekiedy formami charakterystycznymi dla prawa cywilnego. Umowy administracyjno-prawne traktowane są jako umowy zawierane co do zasady przez organy administracji publicznej, których przedmiotem jest realizacja zadań publicznych. A działalność organów administracyjnych z użyciem środków władczych stanowi wyróżnik prawa administracyjnego ${ }^{28}$.

Problematyka swobody umów rodzi liczne kontrowersje z powodu różnego rozumienia pojęcia i zakresu swobody umów. Można bowiem wyróżnić swobodę decydowania o jej zawarciu bądź niezawarciu, swobodę doboru partnera, swobodę treści ukształtowania umowy czy swobodę trybu zawarcia umowy.

Przyjmuje się, że pojęcie „umów w administracji” należy rozumieć bardzo szeroko ${ }^{29}$. Zdaniem P. Steca "umową w administracji sensu stricto nie będzie umowa, w której po żadnej ze stron nie występuje podmiot publiczny, nawet jeśli obowiązek lub upoważnienie do jej zawarcia wynika z przepisów tradycyjnie traktowanych jako administracyjnoprawne ${ }^{\prime \prime 30}$. Niezaprzeczalne jest to, że o umowie w administracji możemy mówić wtedy, gdy jej treść, forma i sposób zawarcia regulowane są w jakimś zakresie przepisami Kodeksu cywilnego. Można zasadnie stwierdzić, że tam, gdzie administracja ma obowiązek działania, a jej władcze formy okazują się mało skuteczne, sięga, o ile jest to możliwe, po środki właściwe prawu cywilnemu. Wszystko to czyni problematykę umów w administracji szczególnie inspirującym polem badawczym. Niemniej organy administracji publicznej nie mogą tego czynić, innymi słowy - zawierać umowy na zasadzie dobrowolności, chyba że przepis szczególny tak stanowi. W najnowszej doktrynie pojawiają się wszakże głosy o kontraktowej kompetencji organów, wywodzonej z art. 2 Konstytucji Rzeczypospolitej ${ }^{31}$.

Zasada równości stron, jako jedna z zasad prawa cywilnego, nie ma zastosowania do umów zawieranych pomiędzy organem administracji

${ }^{28}$ B. Majchrzak, Problemy związane z określeniem prawa administracyjnego (na podstawie poglądów doktryny), „Kwartalnik Prawa Publicznego” 2006, nr 3, s. 156.

${ }^{29}$ P. Stec, Umowy w administracji. Studium..., s. 21.

${ }^{30}$ Ibidem, s. 21 i n.

${ }^{31}$ Z. Cieślik, Konstytucyjne podstawy kontraktowych działań administracji publicznej, w: Prawo administracyjne dziś i jutro, pod red. J. Jagielskiego, M. Wierzbowskiego, Warszawa 2018, s. 189; Konstytucja Rzeczypospolitej Polskiej z dnia 2 IV 1997 r. (Dz. U. 1997 Nr 78, poz. 483 ze zm.). 
a organizacją pozarządową. Jest to raczej iluzja równości stron. Prima facie widać, że w przypadku zlecania zadań publicznych, a w konsekwencji zawierania umów o wsparcie lub powierzanie realizacji zadań, równość stron staje się fikcją. Organ administracji jako dysponent środków budżetowych zawsze jest silniejszą stroną tego stosunku, ponieważ na administracji spoczywa obowiązek wykonywania ustawowo określonych zadań publicznych. Organy administracji zawsze decydują o sposobie ich realizacji i ponoszą za to odpowiedzialność.

Biorąc pod uwagę fakt dysponowania przez jedną ze stron umowy władztwem administracyjnym, pojawia się kwestia określenia drugiej strony umów. Ich wskazanie nastąpiło przez ustawodawcę, ma zatem charakter formalny, w przypadku OPP raczej indywidualny. Kryterium podmiotowe ma zastosowanie tam, gdzie ustawodawca przewiduje umowne uregulowanie zasad udzielenia dotacji bądź grantu.

Najistotniejsze staje się przesądzenie o zakresie autonomii stron. Nie ulega wątpliwości, że autonomia woli stron stanowi jedną z najważniejszych cech prawa cywilnego. Co prawda, nie wynika ona wprost z żadnego przepisu, jednakże trudno wyobrazić sobie istniejące bez niej prawo cywilne. Dlatego nie została wyeliminowana z cywilistyki z okresu PRL ${ }^{32}$ i pozostała obecna w polskim prawie do dziś, choć w codziennym dyskursie prawoznawstwo skupia się zazwyczaj na jej jednym, szczególnym aspekcie, jakim jest swoboda kontraktowa. Nauka prawa cywilnego do elementów składających się na autonomię woli w szerszym ujęciu zalicza: (1) swobodę dokonania lub niedokonania czynności prawnej (swobodę zawierania lub niezawierania umowy); (2) swobodę doboru strony (stron) czynności prawnej; (3) swobodę kształtowania treści czynności prawnej ${ }^{33}$. Przedmiotem kontrowersji jest to, czy do powyższego katalogu należałoby również zaliczyć swobodę wyboru czynności prawnej ${ }^{34}$.

${ }^{32}$ P. Stec, Umowy w administracji publicznej a zasada autonomii woli, w: W kierunku sprawnego państwa. Publicznoprawne instrumenty kształtowania polityki społecznej i gospodarczej, pod red. M. Thorza, E. Halavach, Częstochowa 2008, s. 111 i n.

${ }^{3}$ P. Mróz, Zasada swobody umów, "Studenckie Zeszyty Naukowe” 2003, t. 6, nr 9, s. 49; Z. Radwański, Teoria umów, Warszawa 1997, s. 99-101; Z. Radwański, Uwagi ogólne o autonomii woli, w: II Kongres notariuszy RP. Referaty i opracowania, red. R. Sztyk, Kraków-Kluczbork 1999, s. 267-268; A. Stelmachowski, Ewolucja autonomii woli, w: Tendencje rozwoju prawa cywilnego, red. E. Łętowska, Wrocław 1983, s. 180; W. Czachórski, Zobowiązania. Zarys wykładu, Warszawa 1998, s. 108-109; M. Safjan, Komentarz do art. 353, w: Kodeks cywilny. Zobowiazania - część szczególna, pod red. K. Pietrzykowskiego, Z. Banaszczyka, A. Brzozowskiego, M. Safjana, E. Skowrońskiej-Bocian, J. Szachułowicza, t. 1, wyd. 2, Warszawa 1999, s. 724.

${ }^{34}$ Przeciwnikiem obejmowania autonomią woli stron również formy czynności prawnych jest Z. Radwański, Teoria..., s. 101-103; Uwagi ogólne o autonomii woli, s. 268-271. 
Przesądzenie o zakresie autonomii stron w administracji publicznej jest istotne, organy administracji działają bowiem wyłącznie na podstawie przepisów prawa i w granicach upoważnienia ustawowego, co w znacznym stopniu wyłącza samodzielność i autonomiczność działań, do jakich przywykliśmy w prawie cywilnym. Oczywiste jest więc, że podmiot publiczny działający w świecie prawa prywatnego nie będzie mógł z natury rzeczy cieszyć się taką samą autonomią jak jego "prywatny" kontrahent ${ }^{35}$.

Zdarza się, że pojęcie autonomia traktujemy intuicyjnie, stąd też spotykamy się z próbami przedstawienia tego terminu w sposób opisowy. Ze względu na ramy niniejszego artykułu dokonanie kompletnego przeglądu definicji jest niemożliwe i niecelowe, dlatego poniższe rozważania ograniczono do kilku reprezentatywnych definicji. Zgodnie z definicją S. Grzybowskiego autonomia woli oznacza oparcie przepisów prawa cywilnego na swobodzie dokonania lub niedokonania pewnej czynności prawnej, dowolności ukształtowania treści tej czynności oraz dopuszczalności wyboru dowolnej formy czynności, a co do czynności dwustronnych również na swobodzie doboru drugiego adresata ${ }^{36}$. Inne ujęcie prezentują A. Brzozowski, E. Skowrońska-Bocian i W.J. Kocot, twierdząc, że autonomia woli wyraża się w przyznawaniu przez normy prawa cywilnego stosunkowo dużych możliwości swobodnego angażowania się i kształtowania treści stosunków cywilnoprawnych ${ }^{37}$.

Z kolei M. Safjan osadził autonomię w trzech kontekstach: aksjologiczno-konstytucyjnym, formalnym i pragmatycznym ${ }^{38}$. W pierwszym kontekście autonomia woli stron stanowi realizację konstytucyjnych zasad ochrony godności ludzkiej i wolności, w tym również wolności gospodarczej ${ }^{39}$. W drugim - występuje jako zasada techniczno-prawna, i w tym ujęciu M. Safjan nawiązuje do wypowiedzi S. Grzybowskiego, jest zatem konsekwencją przyznanej przez prawo kompetencji dokonywania czynności prawnych, która obejmuje nie tylko możność decydowania o dokonaniu czynności, ale i o wyborze rodzaju czynności, formie czynności oraz określeniu jej treści ${ }^{40}$. W trzecim kontekście,

\footnotetext{
${ }^{35}$ P. Stec, Umowy w administracji. Studium..., s. 42.

${ }^{36}$ S. Grzybowski, Prawo cywilne. Zarys części ogólnej, Warszawa 1974, s. 32.

${ }^{37}$ A. Brzozowski, E. Skowrońska-Bocian, W.J. Kocot, Prawo cywilne. Część ogólna, Warszawa 2010, s. 40.

${ }^{38}$ M. Safjan, Zasady prawa cywilnego, w: System prawa prywatnego, t. 1: Prawo cywilneczęść ogólna, Warszawa 2012, s. 273 i n.

39 Ibidem, s. 275.

${ }^{40}$ Ibidem, s. 277.
} 
pragmatycznym, autonomia woli stron stanowi elastyczne kształtowanie stosunków prawnych, a także wyznacza dopuszczalny zakres ingerencji ustawodawcy w stosunki cywilnoprawne ${ }^{41}$. Oczywiście, nadal otwarte pozostaje pytanie, jak daleko ustawodawca może się posuwać, ingerując w tak fundamentalną zasadę.

Podstawowe granice w zakresie kształtowania czynności prawnych, a w szczególności umów, wyznacza art. 58 k.c., w myśl którego nieważna jest czynność sprzeczna z ustawą, zasadami współżycia społecznego lub mająca na celu obejście ustawy. Przepis ten odnosi się do wszystkich czynności prawnych bez wyjątku. Obecnie w zakresie dwustronnych czynności prawnych autonomia woli stron jest dodatkowo ograniczana przez zasadę wyrażoną w art. $353^{1}$ k.c. Przepis tego artykułu jest podstawowym przepisem wyrażającym klasyczną ogólną normę kompetencyjną pozwalającą podmiotom prawa cywilnego ustanawiać wiążące je normy postępowania, innymi słowy - nakładać obowiązki i przyznawać uprawnienia w drodze umów. Umowa nie może być zatem co do jej treści lub celu sprzeczna z prawem, zasadami współżycia społecznego i naturą stosunku prawnego. Dwie pierwsze przesłanki nieważności umowy są tożsame z wcześniej wspomnianym art. 58 k.c., trzecia natomiast jest specyficzna dla stosunków umownych, nie można bowiem wykluczyć, że sprzeczność z naturą stosunku prawnego będzie decydować w przypadku innych czynności prawnych o ich niezgodności z ustawą ${ }^{42}$.

Mając zarysowane granice autonomii woli w powszechnym prawie cywilnym, należy przejść do tytułowej kwestii niniejszego wywodu, czyli ustalenia jej granic w umowach zawieranych w administracji, a uściślając - pomiędzy organem administracji publicznej a OPP. Podstawowe ograniczenie autonomii woli w zakresie umów w administracji publicznej dotyczy wyboru trybów jej zawarcia. O ile w powszechnym prawie cywilnym strony mają swobodę decyzji, czy odpowiada im bardziej tryb ofertowy, przetargowy, aukcja czy negocjacje, o tyle umowy $\mathrm{w}$ administracji publicznej mogą być zawierane tylko w ściśle określony przepisami sposób. Ograniczenia w interesującym nas zakresie dotyczą także tego, która ze stron umowy może skutecznie zainicjować procedurę zawarcia umowy.

W przypadku umów w administracji zawieranych pomiędzy organem administracji publicznej a organizacją pozarządową uprawnienie do

\footnotetext{
${ }^{41}$ Ibidem, s. 279.

${ }^{42}$ P. Stec, Umowy w administracji publicznej a zasada autonomii woli, s. 115.
} 
skutecznego zainicjowania procedury zmierzającej do zawarcia umowy należy do podmiotu publicznego. Podmiot publiczny inicjuje procedurę poprzez ogłoszenie konkursu na realizację zadania publicznego. Bez tej czynności nie może dojść do zawarcia wiążącej umowy. Wcześniej podmiot prywatny może złożyć ofertę, aby zachęcić publiczny podmiot do wszczęcia procedury zawarcia umowy, zwłaszcza w trybie niewymagającym przeprowadzenia postępowania konkursowego, jednakże czynności te są tylko propozycjami.

Poza wskazaną sytuacja, w której pierwsze działanie należy do organu publicznego, w u.d.p.p.w. możemy wskazać umowy, w których prawo do zainicjowania procedury należy do grupy obywateli, co ma miejsce w ramach inicjatywy lokalnej. Niemniej jednak złożenia wniosku (petycji) nie można traktować jako oferty w rozumieniu przepisów Kodeksu cywilnego, ponieważ przepisy o działalności pożytku publicznego kwalifikują je jako wniosek w rozumieniu przepisów Kodeksu postępowania administracyjnego (art. $19 \mathrm{~b}$ ust. 2 u.d.p.p.w. $)^{43}$.

Przepisy regulujące zawieranie umów $\mathrm{w}$ administracji publicznej $\mathrm{w}$ istotny sposób ograniczają swobodę doboru stron. W przypadku umów z OPP ustawodawca ograniczył wybór kontrahenta, wskazując wyliczenie enumeratywne podmiotów, które zalicza się do organizacji pozarządowych. Zgodnie z art. 3 ust. 2 u.d.p.p.w. organizacjami pozarządowymi są: (1) niebędące jednostkami sektora finansów publicznych, w rozumieniu ustawy o finansach publicznych; (2) niedziałające w celu osiągnięcia zysku - osoby prawne lub jednostki organizacyjne nieposiadające osobowości prawnej, którym odrębna ustawa przyznaje zdolność prawna, w tym fundacje i stowarzyszenia. Jednocześnie w przepisie tym zawarto zastrzeżenia dotyczące ust. 4 powołanego artykułu, w którym wyliczono zbiór kategorii wyłączonych spod regulacji działu II u.d.p.p.w., mieszczącego przepisy w zakresie działalności pożytku publicznego.

Ponadto na ograniczenia autonomii wpływa przedmiot współdziałania administracji publicznej z organizacjami pozarządowymi (art. 4 u.d.p.p.w.), który w sposób bezpośredni łączy się z problematyką przypisanych organom administracji publicznej zadań publicznych zawartych w art. 7 Ustawy z dnia 8 marca 1990 r. o samorządzie gminnym ${ }^{44}$, art. 4

${ }^{43}$ Kodeks postępowania administracyjnego z dnia 14 VI 1960 r. (tekst jedn. 2018, poz. 2096 ze zm.).

${ }^{44}$ Tekst jedn. Dz.U. 2019, poz. 506 ze zm. 
Ustawy z dnia 5 czerwca 1998 r. o samorządzie powiatowym ${ }^{45}$ oraz art. 14 Ustawy z dnia 5 czerwca 1998 r. o samorządzie województwa ${ }^{46}$.

Nie ulega wątpliwości, że przepisy regulujące zawieranie umów pomiędzy organem administracji a OPP w istotny sposób ograniczają swobodę stron, jeśli chodzi o kształtowanie ich treści. Zasada swobody umów doznaje tak licznych ograniczeń, że można nawet pokusić się o stwierdzenie, iż występuje ona w postaci szczątkowej. Ustawodawca stara się uregulować jak najwięcej kwestii, ponieważ odsyła nawet do posługiwania się wzorcami umownymi zarówno w zakresie oferty, sprawozdania z realizacji zadania, jak i umowy (art. 19 u.d.p.p.w.). W kontekście powyższych ograniczeń podmiot publiczny swobodnie decyduje jedynie w zakresie wysokości przyznania dotacji na realizację zadania publicznego. Z kolei dla OPP autonomia ogranicza się wyłącznie do tego, czy zawrzeć umowę czy nie. Przy tak znacznych wyłączeniach znika istota autonomii i z pewnością nie przypomina tej wypracowanej na gruncie prawa prywatnego.

\section{Zlecanie organizacjom pozarządowym realizacji zadań publicznych w formie powierzania i wspierania}

Ustawa o pożytku publicznym i o wolontariacie przewiduje dwie formy zlecania realizacji zadań publicznych: wspieranie i powierzanie. Obie formy mają związek z udzieleniem dotacji. Wybór formy zlecania w odniesieniu do konkretnych rodzajów zadań publicznych jest uzależniony od decyzji organu administracji. Powierzenie zadań jest formą współpracy, w której przekazuje się całość (100\%) niezbędnych środków (dotacji) na realizację finansowanego zadania (art. 4 ust. 1 u.d.p.p.w.). Wsparcie natomiast to przekazanie części środków (dotacji) na dofinansowanie realizowanego zadania (art. 4 ust. 2 u.d.p.p.w.). Na uwagę zasługuje fakt, że forma wsparcia wymaga przez OPP zabezpieczenia wkładu własnego. Może to być wkład finansowy lub rzeczowy albo praca społeczna (wolontariat). Jest to zasadniczy warunek nawiązania współpracy, a w konsekwencji podpisania umowy.

Zasady współpracy oraz inne główne elementy zawarte w art. 5a ust. 4 u.d.p.p.w. uchwalane są przez organ stanowiący jednostkę samorządu terytorialnego $\mathrm{w}$ formie rocznego lub wieloletniego Programu

\footnotetext{
${ }^{45}$ Tekst jedn. Dz.U. 2019, poz. 511 ze zm.

46 Tekst jedn. Dz.U. 2019, poz. 512 ze zm.
} 
współpracy. Uprzednio projekt Programu podlega obligatoryjnym konsultacjom $z$ organizacjami pozarządowymi oraz podmiotami wymienionymi $w$ art. 3 ust. 3 u.d.p.p.w. ${ }^{47}$

Podstawową procedurą zlecania zadań publicznych jest przeprowadzenie przez organ administracji publicznej otwartego konkursu ofert na realizację zadań publicznych. Ogłoszenie konkursu zawiera podstawowy zbiór warunków, które należy spełnić. Innymi słowy, można go przyrównać do specyfikacji istotnych warunków zamówienia z Ustawy z dnia 29 stycznia 2004 r. Prawo zamówień publicznych ${ }^{48}$.

W pewnych szczególnych sytuacjach, w celu zapobieżenia skutkom nadzwyczajnych zdarzeń, takich jak wystąpienie klęski żywiołowej, katastrofy naturalnej lub awarii technicznej, można zlecić organizacjom pozarządowym realizację zadania z pominięciem procedury otwartego konkursu. Realizację zadania publicznego z jego pominięciem stosuje się też w przypadku tzw. małych grantów, jednakże istnieją obligatoryjne warunki, które należy spełnić. Ustawodawca w art. 19a pkt 1 i 2 u.d.p.p.w. wskazuje, że wysokość dofinansowania lub finansowania zadania publicznego nie może wtedy przekraczać kwoty 10 000,00 zł oraz to, że zadania publiczne mają być realizowane w okresie nie dłuższym niż 90 dni. W kwestii ogłaszania konkursów na uwagę zasługuje brak procedur odwoławczych, a także sądowych lub jakiejkolwiek innej kontroli nad ich rozstrzygnięciem.

Najczęściej stosowaną formą współpracy organu administracji publicznej z organizacjami pozarządowymi jest zlecanie realizacji zadań publicznych w formie wsparcia. Forma tej współpracy nie jest wolna od wad, ponieważ jest, jak się wydaje, formą outsourcingu, czyli czynienia z podmiotów trzeciego sektora zależnego klienta administracji. Organizacja pozarządowa występująca w roli partnera społecznego dysponuje zatem ograniczoną autonomią finansową i organizacyjną.

Umowy zawierane pomiędzy organem administracji a organizacją pozarządową wykazują pewne podobieństwa do umowy darowizny z poleceniem ${ }^{49}$, ale nie są $\mathrm{z}$ nią równoznaczne. Pomijając kwestię podmiotową stron, należy zwrócić uwagę, że przy umowach wsparcia darczyńca nie jest niczyim wierzycielem, a umowy są jednostronnie zobowiązujące. Natomiast z umową dotacji mamy do czynienia ze

${ }^{47}$ Wyrok Wojewódzkiego Sądu Administracyjnego (WSA) we Wrocławiu z 11 VI 2013 r., sygn. III/SA/Wr 124/13, LEX nr 1330073.

${ }^{48}$ Dz.U. 2018, poz.1986 ze zm.

${ }^{49}$ Artykuł 888 i n. k.c. 
zobowiązaniem dwustronnym. Na obu stronach, zarówno organie administracji publicznej, jak i na dotowanym podmiocie, ciążą ściśle określone obowiązki.

Zawierane umowy mają zaostrzoną klasyfikację podmiotową. Mogą być zawierane, jak już wspomniano, przez podmioty enumeratywnie wskazane w art. 3 u.d.p.p.w., przy czym o tym, który z aplikujących podmiotów stanie się jedną ze stron umowy, zdecyduje wynik konkursu. Następuje to poprzez tzw. fishing pool, a więc "łowienie partnerów” do realizacji zadań publicznych opartych na zasadzie jawności.

Organy administracji publicznej finansują lub dofinansowują tylko te zadania, które wylicza art. 4 ust. 1 u.d.p.p.w. WSA we Wrocławiu w wyroku z dnia 18 listopada 2009 r. stanął na stanowisku, że „nie każde działanie, które przynosi pozytywne efekty w jednym z obszarów wymienionych w art. 4 ustawy z 2003 r. o działalności pożytku publicznego i o wolontariacie podejmowane $\mathrm{z}$ uwzględnieniem korzystnych efektów w tym obszarze, jest działalnością pożytku publicznego, o jakiej mowa w art. 3 ustawy. Takimi działaniami będą jedynie te, które podejmowane są w celu realizacji zadań wymienionych $\mathrm{w}$ art. $4^{\prime \prime 50}$. Oznacza to, że podejmowanie działań w sferze zadań publicznych musi mieć wyraźnie cel bezpośredni oraz określony sposób realizacji, ponieważ działań tych nie można podejmować niejako przez przypadek $^{51}$. Wprowadzenie tego ograniczenia jest uzasadnione szczególnym charakterem działalności mieszczącej się w sferze zadań publicznych. Ponadto wybór podmiotu, któremu organ administracji zleca w trybie umowy realizację określonego zadania publicznego, jest ograniczony do podmiotów wyspecjalizowanych, prowadzących działalność w zakresie objętym zadaniem.

Zaakcentować należy fakt, że delegacja ustawowa zawarta w art. 19 u.d.p.p.w. odsyła do Rozporządzenia Przewodniczącego Komitetu do spraw Pożytku Publicznego z dnia 24 października 2018 r. w sprawie wzorów ofert i ramowych wzorów umów, dotyczącego realizacji zadań publicznych oraz wzorów sprawozdań z wykonania tych zadań (dalej: Rozporządzenie), pomimo że wzorce umów nie mogą być traktowane jako źródło prawa powszechnie obowiązujące ${ }^{52}$. Treść umowy o powierzenie lub wsparcie kształtowana jest zatem przez Rozporządzenie, które w znaczący sposób ogranicza swobodę kontraktowania. Jednakże

\footnotetext{
${ }^{50}$ Wyrok WSA we Wrocławiu z 18 XI 2009 r., sygn. I SA/Wr 1365/09, LEX nr 588942.

${ }^{51}$ P. Staszczyk, op. cit., s. 22.

${ }^{52}$ E. Łętowska, Ochrona niektórych praw konsumentów, Warszawa 2001, s. 72.
} 
poprzez zgodne oświadczenie woli dochodzi do ich zawarcia ${ }^{53}$. Wzór umowy zgodnie $\mathrm{z}$ Rozporządzeniem nie podlega modyfikacjom w zakresie postanowień umowy, obie strony muszą więc przyjąć bez jakichkolwiek zmian typ umowy wraz z jej treścią uregulowaną normatywnie. Są one przepisami prawa, nie mogą zatem być zmieniane wyrokiem sądu, tak jak w przypadku wzorców kontraktowych, gdzie ingerencja sądu jest możliwa ${ }^{54}$. Umowa o wsparcie lub powierzenie realizacji zadań musi mieć formę pisemna, gdyż tylko umowa podpisana przez obie strony jest ważna i gwarantuje przekazanie dotacji.

W zakresie rozwiązania umowy o powierzenie lub wsparcie realizacji zadania publicznego możliwe są trzy sytuacje. Sytuacje te określa ramowy wzór umowy zawarty w Rozporządzeniu (§ 11-13 załącznika nr 3). Są to:

1. rozwiązanie za porozumieniem stron,

2. odstąpienie od umowy przez zleceniobiorcę,

3. rozwiązanie umowy przez zleceniodawcę.

W sytuacji rozwiązania umowy za porozumieniem stron umowa ta może być rozwiązana w przypadku stwierdzenia okoliczności, za które strony nie ponoszą odpowiedzialności, a które uniemożliwiają jej wykonanie. Może to być np. klęska żywiołowa. Z kolei odstąpienie od umowy przez zleceniobiorcę może nastąpić w przypadku, gdy zaistnieją okoliczności uniemożliwiające realizację zadania. Natomiast w przypadku rozwiązania umowy przez zleceniodawcę umowa ta może być rozwiązana ze skutkiem natychmiastowym wtedy, gdy dotacja jest wykorzystywana niezgodnie z przeznaczeniem lub pobrana w nadmiernej wysokości bądź nienależnie, tj. bez podstawy prawnej.

Wszelkie spory dotyczące zasadności zobowiązania do zwrotu kwoty dotacji czy też jej wymiaru są rozstrzygane na drodze postępowania cywilnego $^{55}$. Za środki finansowe wykorzystane niezgodnie z przeznaczeniem można uznać zwłaszcza: środki wydatkowane niezgodnie z kosztorysem oraz środki wydatkowane przed podpisaniem umowy, ponieważ wówczas mielibyśmy do czynienia z refundacja, której nie przewiduje u.d.p.p.w. i ustawa o finansach publicznych, a także środki wykorzystane po zakończeniu realizacji zadania lub wykorzystane na inny cel. Wskazany w ofercie okres zakończenia realizacji zadania oznacza też zakończenie

${ }^{53}$ Ibidem, s. 302.

${ }^{54}$ P. Stec, Umowy w administracji. Studium..., s. 72 i n.

${ }_{55} \mathrm{~J}$. Kosowski, Wspótpraca jednostek samorządu terytorialnego z organizacjami pozarzadowymi, Warszawa 2012, s. 142. 
wydatkowania środków. Powyższe potwierdza wyrok Najwyższego Sądu Administracyjnego (NSA) z dnia 3 września 2013 r., w którym stwierdza się, że "wykorzystanie dotacji celowej z budżetu państwa niezgodnie z przeznaczeniem polega w szczególności na zapłacie środków pochodzących z dotacji na inne zadania niż te, na które dotacja była udzielona, albo za realizację innych celów niż cele wskazane w przepisach odrębnych, stanowiących o sposobie udzielenia i rozliczenia dotacji" ${ }^{\prime 56}$.

\section{Zlecenie organizacjom pozarządowym realizacji zadań w ramach inicjatywy lokalnej}

Instytucja inicjatywy lokalnej została wprowadzona do polskiego systemu prawnego nowelizacją u.d.p.p.w. z dnia 22 stycznia 2010 r. Ma ona służyć pobudzeniu działań obywateli w celu rozwiązywania ważnych spraw dla społeczności lokalnych ${ }^{57}$ oraz wspomagać ich rozwój i integrację. Sposobem osiągnięcia tego celu mają być umowy zawierane między reprezentantami lub pełnomocnikami danej społeczności a organami administracji publicznej służące realizacji zadań publicznych tudzież postulatów określonych ustawowo i wskazanych we wniosku o realizację inicjatywy ${ }^{58}$.

Istotą działań inicjatywy lokalnej jest przede wszystkim wykorzystanie potencjału społecznego mieszkańców i zaangażowanie w działanie. Można zatem wywnioskować, że z jednej strony instytucja inicjatywy jest narzędziem realizacji zadań publicznych, a z drugiej - mechanizmem wykorzystania aktywności i zdolności mieszkańców do „brania spraw w swoje ręce ${ }^{\prime \prime 59}$.

Bez wątpienia, realizowanie inicjatywy lokalnej powinno być najczęściej stosowane na najniższym szczeblu terytorialnym, czyli w gminie, ze względu na najbliższe i najmocniejsze relacje pomiędzy jednostką a mieszkańcami ${ }^{60}$. Mieszkańcy mogą więc bezpośrednio lub za pośred-

\footnotetext{
${ }^{56}$ Wyrok NSA z 3 IX 2013 r., sygn. II GSK 711/12, LEX nr 1415160.

${ }^{57}$ J. Kosowski, op. cit., s. 196.

${ }^{58}$ Uzasadnienie rządowego projektu ustawy o zmianie ustawy o działalności pożytku publicznego i o wolontariacie oraz niektórych innych ustaw z dnia 16 II 2009 r. (druk sejmowy nr 1727/VI kadencja, s. 4 i n.).

${ }^{59}$ Ł. Waszak, 3W Jak korzystać z inicjatywy lokalnej, Warszawa 2014, s. 3.

${ }^{60}$ K. Rzeczkowska, Nowa forma wspótpracy społeczeństwa z samorzadem terytorialnym kilka uwag o realizacji inicjatywy lokalnej, w: Organizacje pozarządowe a samorzad - 25 lat doświadczeń, pod red. U. Szymańskiej, P. Majera, M. Falej, Olsztyn 2016, s. 110.
} 
nictwem organizacji pozarządowej wystąpić z wnioskiem o realizację zadań w ramach inicjatywy lokalnej. Rozpatrzenie wniosku przez organ jednostki samorządu terytorialnego jest najważniejsze, ponieważ poprzedza prawdopodobieństwo zawarcia umowy na wykonanie zadania publicznego.

W praktyce problematyczna może być sytuacja, kiedy wniosek zostaje złożony za pośrednictwem organizacji samorządowych lub innych podmiotów prowadzących działalność pożytku publicznego. Już na wstępie wydaje się, że art. 19b u.d.p.p.w. został wyjątkowo niefortunnie sformułowany. Po pierwsze, użycie przez ustawodawcę liczby mnogiej wskazuje, że skuteczne złożenie wniosku wymagałoby pośrednictwa co najmniej dwóch działających organizacji lub innych podmiotów. Po drugie, wątpliwości budzi charakter prawny pośrednictwa, co pociąga za sobą kilka uwag. Pierwsza to taka, że organizacje pozarządowe można uznać za zastępcę pośredniego, a umowa jest zawierana w ich imieniu na "rachunek" mieszkańców. Konstrukcja takiej umowy byłaby jednak utrudniona w stosowaniu z powodu braku zapisów w ustawie dotyczących wzajemnych praw i obowiązków stron. Kolejna uwaga, że organizacje pozarządowe działają jako pełnomocnik mieszkańców. Co prawda, do udzielenia pełnomocnictwa nie potrzeba byłoby szczególnej regulacji ustawowej, lecz nie jest to klarowna sytuacja. I następna uwaga, że organizacje pozarządowe występują w roli posłańca i przenoszą oświadczenie woli mieszkańców ${ }^{61}$.

Mieszkańcy realizują swoje zamierzenia i składają wniosek do jednostki samorządu terytorialnego (j.s.t.), na terenie której mają miejsce zamieszkania lub siedzibę, zazwyczaj za pośrednictwem pełnomocnika, czyli organizacji pozarządowych, takich jak: ochotnicze straże pożarne, kluby sportowe i coraz częściej koła gospodyń wiejskich, które na mocy Ustawy z dnia 9 listopada 2018 r. o kołach gospodyń wiejskich ${ }^{62}$ z momentem wpisu do rejestru nabywają osobowość prawną. Funkcję pełnomocnika mieszkańców mogą pełnić także parafie i oddziały "Caritasu" oraz inne podmioty tworzone przez Kościół katolicki lub związki wyznaniowe, pod warunkiem że ich cele obejmują prowadzenie działalności pożytku publicznego. Z listy podmiotów mogących występować jako pełnomocnicy mieszkańców zostały wykluczone jedynie spółdzielnie socjalne.

\footnotetext{
${ }^{61}$ P. Stec, Umowy w administracji. Studium..., s. 46.

${ }^{62}$ Tekst jedn. Dz.U. 2018, poz. 2212.
} 
W przypadku inicjatywy lokalnej jako narzędzia aktywności zakłada się, że mieszkańcy sami identyfikują obszar działań i sami określają propozycję zmierzającą do osiągnięcia celu. Wydawać by się mogło, że w tej materii występuje większa swoboda mieszkańców do zainicjowania propozycji zadania, lecz nie jest to takie oczywiste, ponieważ przy wyborze rodzaju zgłaszanej inicjatywy zadanie publiczne musi się mieścić $\mathrm{w}$ zakresie zadań określonych $\mathrm{w}$ art. $19 \mathrm{~b}$ ust. 1 u.d.p.p.w., a tym samym w sferze zadań j.s.t.

Umowa na wykonanie inicjatywy lokalnej jest podstawowym i najpełniejszym dokumentem opisującym zakres realizacji zadania. Najważniejszym składnikiem umowy jest określenie jej przedmiotu, czyli wskazanie konkretnych zadań i czynności wraz z harmonogramem i kosztorysem. Stronami umowy są organ administracji publicznej (wójt bądź burmistrz) oraz autor wniosku będący osobą fizyczną lub grupa osób albo ich pełnomocnik ${ }^{63}$. Umowę w imieniu mieszkańców podpisują osoby upoważnione, tj. te same osoby, które podpisały wniosek o realizację zadania publicznego, a w imieniu organizacji pozarządowej osoba lub osoby, które są wyznaczone w statucie organizacji do jej reprezentowania.

Jak wynika z dyspozycji art. 19h u.d.p.p.w., w zakresie nieuregulowanym w ustawie do umowy o wykonanie inicjatywy lokalnej stosuje się przepisy ustawy Kodeks cywilny. Ponadto nie ulega wątpliwości, że umowa o realizację zadania publicznego $\mathrm{w}$ ramach inicjatywy lokalnej ma bliski związek z umową cywilnoprawną, choć jest to specyficzny rodzaj umowy, ponieważ nie mieści się wśród typów umów uregulowanych w Kodeksie cywilnym. Zapewne nie jest to umowa nazwana, umowa zlecenie ani umowa o dzieło, lecz umowa nienazwana ${ }^{64}$, której treść strony mogą kształtować w ograniczony sposób przy równoczesnym zachowaniu elementów wymaganych przez przepisy u.d.p.p.w.

Ograniczenia te, z punktu widzenia realizacji zadania według formuły przewidzianej dla inicjatywy lokalnej, mają przede wszystkim zapewnić istnienie współpracy między jednostką samorządu terytorialnego a jej mieszkańcami, z położeniem szczególnego nacisku na konieczność wniesienia wkładu mieszkańców w postaci określonego świadczenia i podziału zadań pomiędzy organem jednostki samorządu terytorialnego a mieszkańcami realizującymi określone przez nich wspólnie zadanie

${ }^{63}$ J. Kosowski, op. cit., s. 202.

${ }^{64}$ Rozstrzygnięcie nadzorcze Wojewody Dolnośląskiego z 30 VII 2014 r., sygn. NK-N.4131.136.79.2014.AS (Dz.Urz. Woj. Dolnośląskiego 2014, poz. 3452). 
publiczne. W tym miejscu nasuwa się refleksja, że być może jest to nienazwana umowa o świadczenie usług z mocy art. 750 k.c. Przepis ten reguluje reżim prawny umów, które łącznie spełniają dwie przesłanki: są umowami o świadczenie usług, a zarazem nie są uregulowane innymi przepisami. Umowy, do których stosuje się uregulowania zawarte $\mathrm{w}$ tym artykule, charakteryzują się tym, że ich przedmiotem jest świadczenie usług, przy czym umowa taka może dotyczyć dokonania jednej usługi, większej określonej liczby usług lub stałego świadczenia usług określonego rodzaju. Umowy takie mogą mieć charakter odpłatny bądź nieodpłatny i są umowami konsensualnymi. Ich stronami mogą być wszelkie podmioty prawa cywilnego, a więc osoby fizyczne, osoby prawne i jednostki organizacyjne niebędące osobami prawnymi, którym ustawa przyznaje zdolność prawną ${ }^{65}$. Ponadto stronami mogą być m.in. podmioty występujące w obrocie, w szczególności osoby prawne czy jednostki organizacyjne nieprowadzące działalności gospodarczej. Cechą charakterystyczną takich umów jest również to, że zazwyczaj są to umowy oparte na zaufaniu między stronami, a zlecający powierza usługę jej wykonania, mając zaufanie do umiejętności, kwalifikacji oraz wiedzy ${ }^{66}$.

Na uwagę zasługuje też fakt, że ustawodawca wykluczył kompetencję organu stanowiącego j.s.t. do uregulowania w drodze aktu prawa miejscowego jakichkolwiek kwestii dotyczących umów na realizację zadania publicznego ${ }^{67}$. Organ stanowiący nie ma zatem prawnego umocowania do określenia jej wzoru ${ }^{68}$ ani treści ${ }^{69}$. Oznacza to tym samym, że do takiej umowy ma zastosowanie art. $353^{1}$ k.c., zgodnie z którym strony zawierające umowę mogą ułożyć stosunek prawny według uznania, byleby jego treść lub cel nie sprzeciwiały się właściwości stosunku,

${ }^{65}$ A. Kidyba, Kodeks cywilny. Komentarz, t. 3: Zobowiąania - część szczególna, wyd. 2, LEX/el. 2014.

${ }^{66}$ M. Nesterowicz, Komentarz do art. 750, w: Kodeks cywilny z komentarzem. Zobowiazania - czesść ogólna, dzieło zbiorowe, udział autorski dotyczący zobowiązań t. 2, pod red. J. Winiarza, Warszawa 1989, s. 692; wyrok Sądu Apelacyjnego w Warszawie z 15 IX 2008 r., sygn. IACa 84/08, „Apel Warszawa” 2009, nr 2, poz. 14.

${ }^{67}$ Rozstrzygnięcie nadzorcze Wojewody Wielkopolskiego z 14 IV 2015 r., sygn. KN-I.4131.1.68.2015.22 (Dz.Urz. Woj. Wielkopolskiego 2015, poz. 2523); rozstrzygnięcie nadzorcze Wojewody Dolnośląskiego z 14 II 2012 r., sygn. NK-N13.41.3191.2012. JT1-1 (Dz.Urz. Woj. Dolnośląskiego 2012, poz. 705).

${ }^{68}$ Rozstrzygnięcie nadzorcze Wojewody Dolnośląskiego z 14 II 2012 r., sygn. NK-N13.41.3191.2012. JT1-1.

${ }^{69}$ Rozstrzygnięcie nadzorcze Wojewody Śląskiego z 30 X 2013 r., sygn. NPII.4131.1.488.2013 (Dz.Urz. Woj. Śląskiego 2013, poz. 6340). 
ustawie oraz zasadom współżycia społecznego. Z punktu widzenia klasyfikacji umów prawa cywilnego umowa na wykonanie inicjatywy lokalnej nie może być więc traktowana jako przykład typowej umowy cywilnoprawnej, ale być może mogłaby się mieścić w kodeksowej typologii świadczenia usług.

W przypadku inicjatywy lokalnej w Rozporządzeniu z 2018 r. odstąpiono od określenia ramowego wzoru umowy ${ }^{70}$, jak miało to miejsce we wcześniej rozważanych formach realizacji zadań publicznych. Oznacza to, że u.d.p.p.w. pozostawia swobodę jej kształtowania stronom na podstawie przepisów k.c. ${ }^{71}$, zgodnie z którymi strony zawierające umowę mogą ułożyć stosunek prawny w taki sposób, aby jego cel lub treść nie sprzeciwiały się właściwości stosunku, ustawie oraz zasadom współżycia społecznego $^{72}$. Warto też zauważyć, że u.d.p.p.w. nie określa konsekwencji niewykonania lub nienależytego wykonania umowy. Brakuje także delegacji ustawowej dla organu stanowiącego j.s.t., by tę kwestię uregulować w drodze aktu prawa miejscowego. Zgodnie z art. 19h u.d.p.p.w. zastosowanie w tej materii będą zatem miały przepisy tytułu VII Kodeksu cywilnego - „Wykonanie zobowiązań i skutki ich niewykonania”.

W zakresie zawarcia umowy $\mathrm{w}$ ramach inicjatywy lokalnej podkreślenia wymaga to, że w odróżnieniu od umów w przedmiocie powierzenia lub wsparcia realizacji zadań publicznych wnioskodawca nie otrzymuje środków finansowych na sfinansowanie lub dofinansowanie zadania. Innymi słowy, nie jest udzielana dotacja ${ }^{73}$. Współpraca polega na zobowiązaniu wnioskodawcy do świadczenia pracy społecznej, na świadczeniach pieniężnych lub rzeczowych (art. 19e u.d.p.p.w. ${ }^{74}$. Niemniej jednak praktyka udowadnia, że samorządy zazwyczaj udzielają wsparcia finansowego i zabezpieczają środki finansowe na kolejny rok budżetowy bez przypisywania ich do konkretnych zadań. Wsparcie

${ }^{70}$ D. Sześciło, Samoobstugowe państwo dobrobytu. Czy obywatelska koprodukcja uratuje ustugi publiczne, Warszawa 2015, s. 136.

${ }^{71}$ J. Blicharz, Komentarz do art. 19d u.d.p.p.w., Warszawa 2012, s. 117.

${ }^{72}$ Rozstrzygnięcie nadzorcze Wojewody Dolnośląskiego z 14 II 2012 r., sygn. NK-N13.41.3191.2012. JT1-1.

${ }^{73}$ Uchwała Regionalnej Izby Obrachunkowej w Rzeszowie z 21 IX 2010 r., XXIII/4365/10 „Orzecznictwo w Sprawach Samorządowych” 2011, nr 1, LEX nr 726589; uchwała Regionalnej Izby Obrachunkowej w Zielonej Górze z 9 VI 2010 r., 176/2010 (Dz.Urz. Woj. Lubuskiego 2010, poz. 828).

${ }^{74}$ Rozstrzygnięcie nadzorcze Wojewody Śląskiego z 5 IV 2013 r., sygn. NP-II.4131. 1.191.2013 (Dz. Urz. Woj. Śląskiego 2013, poz. 3337). 
finansowe polega na dokonaniu płatności bezpośrednio przez j.s.t. w części uwzględnionej w harmonogramie realizacji zadania publicznego.

Bezsprzecznie umowa w ramach inicjatywy lokalnej nie może być traktowana jak przykład typowej umowy cywilnoprawnej. Wprawdzie ustawodawca dopuszcza stosowanie kodeksowej zasady swobody umów, lecz ulega ona w pewnym zakresie ograniczeniom przewidzianym w ustawie o działalności pożytku publicznego i o wolontariacie. Zastosowanie ograniczeń ma zapewnić współpracę między stronami i zaangażowanie $\mathrm{w}$ realizację zadania publicznego.

\section{Umowy partnerskie}

Współpraca organów administracji publicznej z organizacjami pozarządowymi odnosi się także do realizacji projektów partnerskich na podstawie umowy lub porozumienia, o których mowa w art. 28a Ustawy z dnia 6 grudnia 2006 r. o zasadach prowadzenia polityki rozwoju ${ }^{75}$. W sytuacji gdy w polskim ustawodawstwie nie do końca sprecyzowane jest pojęcie „umowa administracyjna”, wprowadzenie kolejnego terminu „umowa partnerska” może jeszcze bardziej dezorientować. Instytucjami publicznymi w sferze polityki rozwoju państwa są zarówno organy administracji rządowej, jak i samorządowej. Polityka rozwoju jest jednym z kilku głównych członów, które składają się na politykę wewnętrzną państwa. Zadaniem polityki rozwoju jest maksymalne jej skoordynowanie, w tym ustalenie jej nadrzędnych celów, stworzenie zasad harmonizacji poszczególnych instytucji publicznych uczestniczących w jej prowadzeniu w taki sposób, aby nie były ze sobą sprzeczne, a w konsekwencji by wysiłek zarówno organizacyjny, jak i finansowy był optymalnie wykorzystany zgodnie z założonymi celami.

Celem tworzenia partnerstw projektowych jest zwiększenie zakresu oddziaływań przedsięwzięć oraz zapewnienie kompleksowej realizacji zadań tudzież celów społeczno-gospodarczych ${ }^{76}$. Z pewnością wykorzystanie wiedzy i doświadczenia różnych podmiotów biorących udział w partnerstwie wpływa korzystnie na wielostronne podejście do zidentyfikowanego obszaru działania. Partnerstwa mogą być powoływane na rzecz realizacji projektów obejmujących inwestycje oraz innego rodzaju

75 Tekst jedn. Dz.U. 2018, poz. 1307 ze zm.

${ }^{76}$ E. Kornberger-Sokołowska, J. Zdanukiewicz, R. Cieślak, Jednostki samorządu terytorialnego jako beneficjenci środków europejskich, Warszawa 2012, s. 235. 
przedsięwzięcia, w szczególności edukacyjne i szkoleniowe oraz związane $z$ aktywizacją społeczną na danym obszarze. A zatem partnerstwa projektowe obejmują zarówno porozumienia, stowarzyszenia i związki jednostek organów administracji publicznej, jak i wszelkie przewidziane prawem formy współpracy z podmiotami prywatnymi. Organy administracji publicznej mogą tworzyć partnerstwa na każdym szczeblu terytorialnym, czyli mogą przystępować do nich przede wszystkim na zasadach wskazanych w ustawach ustrojowych, $\mathrm{tj}$. ustawie o samorządzie gminnym, powiatowym i wojewódzkim, a także w przepisach odrębnych, np. Kodeksie cywilnym.

W procesie partnerstwa duże znaczenie mają wykonawcy i podwykonawcy, a wśród nich mogą też występować podmioty realizujące zadania publiczne na podstawie u.d.p.p.w. W literaturze wskazano jednak, że w obecnych realiach prawnych możliwość prowadzenia współpracy partnerskiej pomiędzy organami administracji publicznej a organizacjami pozarządowymi jest ograniczona ze względu na następujące przesłanki:

- udział organizacji społecznych w realizacji zadań publicznych ogranicza się przede wszystkim do przeprowadzania konsultacji lub współtworzenia dokumentów programowych, ewentualnie do podpisywania listów intencyjnych dotyczących rozwoju społeczno-gospodarczego danego obszaru administracyjnego;

- realizacja zadań publicznych wspólnie z podmiotami prywatnymi odbywa się zazwyczaj poprzez zlecenie wykonania robót budowlanych, dostaw lub usług w trybie zamówień publicznych albo powierzanie lub wspieranie realizacji tych zadań w trybie ustawy o działalności pożytku publicznego i o wolontariacie;

- polski system prawny ze względu na wymogi regulacji Unii Europejskiej oraz prawa krajowego w zakresie pomocy publicznej i zasad konkurencyjności utrudnia wspólną realizację projektu, gdy wiąże się to $\mathrm{z}$ wydatkowaniem środków publicznych lub uzyskiwaniem innych korzyści przez podmioty prywatne, pomimo że istota projektu partnerskiego polega na wspólnym planowaniu, angażowaniu zasobów oraz na realizacji projektu ${ }^{77}$.

Współpraca na podstawie umowy partnerskiej odnosi się do realizacji wspólnego projektu w ramach programu operacyjnego, czyli projektu partnerskiego. Inicjatorem zawarcia takiego partnerstwa jest instytucja

\footnotetext{
77 Ibidem, s. 245.
} 
zarządzająca (zarząd województwa), która w drodze porozumienia powierza instytucji pośredniczącej część zadań związanych z realizacją programu operacyjnego. Instytucją pośredniczącą może być inny organ administracji publicznej niższego szczebla (powiat, gmina) lub inne jednostki sektora finansów publicznych.

W przypadku umowy partnerskiej pomiędzy organami administracji a organizacją pozarządową umowa reguluje przede wszystkim zadania i obowiązki podmiotów. Obligatoryjnymi składnikami są:

1. zasady wspólnego zarządzania projektem,

2. sposób przekazywania przez beneficjenta środków finansowych na pokrycie niezbędnych kosztów ponoszonych przez partnerów na realizację zadań $\mathrm{w}$ ramach projektu.

W ramach umowy organizacja pozarządowa może zostać zobowiązana do wniesienia do projektu w zakresie zadeklarowanym w ofercie następujących zasobów:

1. ludzkich - główną rolę odgrywają eksperci, praca społeczna członków organizacji oraz wolontariuszy;

2. organizacyjnych - przygotowanie różnych materiałów;

3. technicznych - udostępnienie sprzętu i maszyn;

4. know-how (wiedzieć-jak) - przekazanie konkretnej wiedzy technicznej z danej dziedziny;

5. finansowych.

Ustawa o zasadach prowadzenia polityki rozwoju, przewidując różne formy aktywności poszczególnych instytucji zaangażowanych w prowadzenie polityki rozwoju, powoduje zatem przenikanie się administracyjnoprawnej i cywilnoprawnej metody regulacji, z umową na czele. Zauważalne jest to zarówno w ujęciu makro, czyli relacji administracji centralnej z administracją na szczeblu lokalnym, jak i ujęciu mikro, czyli relacji instytucji prawa publicznego z poszczególnymi beneficjentami. Innymi słowy, ustawa o zasadach prowadzenia polityki rozwoju dostarcza istotnych przykładów dwojakiego posługiwania się umową w sektorze publicznym.

\section{Podsumowanie}

Instytucjami publicznymi w sferze działalności pożytku publicznego są organy administracji publicznej oraz organizacje pozarządowe. Ustawa o działalności pożytku publicznego i o wolontariacie przewiduje różne 
formy aktywności jednostek zaangażowanych w działanie. Niewątpliwie, aktywność organizacji pozarządowych stanowi wyraz rozwoju społeczeństwa obywatelskiego, skierowanego na działanie niezależnie od instytucji państwowych.

Zarysowane rozbieżności dowodzą braku uporządkowania, żeby nie powiedzieć - chaosu w zakresie problematyki umów zawieranych pomiędzy organem administracji publicznej a organizacją pozarządową w celu realizacji zadań publicznych. Bez wątpienia, umowa jako forma działania administracji nigdy nie będzie miała identycznej natury prawnej jak umowa zawierana między podmiotami prywatnymi. Administracja, stosując prywatnoprawne formy działania, nie staje się takim samym podmiotem prawa jak każdy podmiot prywatny, a w konsekwencji nie jest zwolniona z przestrzegania fundamentalnych zasad i wartości konstytucyjnych, które zostały ustanowione dla ochrony praw i wolności obywatelskich. W orzecznictwie wyraża się poglą $\mathrm{d}^{78}$, że fakt posłużenia się przez administrację publiczną umową przesądza o tym, że występowanie jako równorzędny podmiot z obywatelem jest przejawem stereotypowego myślenia, zgodnie z którym sama forma umowy gwarantuje równość stron.

Prawo cywilne jako regulator aktywności podmiotów prawa publicznego wymaga określonych modyfikacji i odstępstw w stosunku do tradycyjnej cywilistyki. Są one bowiem wymuszone specyfiką tych podmiotów. Bez ich dokonania może zaś dochodzić do naruszenia zasad i wartości konstytucyjnych w przypadku posługiwania się przez administrację cywilnoprawnymi formami działania. Należy też zwrócić uwagę, że wiele lat temu wprowadzone przez administratywistów rozróżnienie na prawo administracyjne sensu stricto i prawo administracyjne sensu largo dowodzi, iż sami administratywiści próbują objąć zakresem swych badań obszary zastrzeżone dla cywilistyki. Powyższy wywód skłania do wniosku, że na pewno pojawia się pokusa generalnego uregulowania kwestii swobody umów w administracji. Niewątpliwie, brakuje odpowiedzi w treści przepisów samorządowych na pytanie, czy dopuszczalne jest stosowanie przepisów prawa cywilnego do tej instytucji. Temat umów w administracji wymaga zapewne zaangażowania zarówno administratywistów, jak i cywilistów, a także poddania umów analizom interdyscyplinarnym. Być może ponowne rozważenie wprowadzenia odrębnej umowy w administracji przyniosłoby korzyść

${ }^{78}$ Wyrok Sądu Najwyższego z 11 V 2012 r., sygn. II CSK 545/11, LEX nr 1229959. 
zarówno z punktu widzenia teoretycznego, jak i praktycznego, a tym samym moglibyśmy uzyskać aprobatę lub dezaprobatę dla jej stosowania.

\section{CIVIL LAW ASPECTS OF THE AGREEMENTS TO IMPLEMENT PUBLIC TASKS ENTERED INTO BY PUBLIC ADMINISTRATION BODIES AND NON-GOVERNMENTAL ORGANIZATIONS}

\section{Su m mary}

The article focuses on selected aspects of collaboration between public authorities and public benefit organizations (PBOs). PBOs not only enable the development of active citizenship, but also contribute to the effective implementation of public tasks, thus helping the authorities in implementing their statutory duties. An outcome of the collaboration may be, among other things, an agreement to implement certain tasks, taking the form of, for example, the realization of a task or the support provided for its realization following competitive tendering and in justified cases without the tender, or performed within the framework of a local initiative. The main focus of the article is to determine the scope of the autonomy of the parties in the classic approach, keeping in mind that the autonomy is one of the main principles governing civil law. Parties in a civil law contract must be able to create autonomous relationships. Consequently, in order to fulfil its functions, civil law must be an open system which regulates typical situations in a non-authoritative manner. The essential question seems to be to what extent this attitude may be transposed to public law. Undoubtedly, an agreement as a form of an administrative activity will never have the same legal nature as an agreement concluded between private parties. An administrative body that applies private law forms of action does not become subject to the same rights as a private entity and, consequently, is not exempt from the obligation to comply with the fundamental constitutional principles and values that have been established with a view of protecting civil rights and freedoms.

Keywords: public authorities - non-governmental organizations - agreement autonomy 